\title{
Narrativas fílmicas documentales y dilemas de subjetivación de la experiencia. Estudios de casos argentinos
}

\author{
Mariné Nicola \\ CIECEHC - Centro de Investigaciones \\ en Estudios Culturales, Educativos, Históricos \\ y Comunicacionales.
}

FHUC-FBCB, UNL

\section{Resumen}

En este artículo nos abocamos al análisis de la producción fílmica documental cuyas narrativas se centran en la última dictadura cívico-militar argentina (1976-I983) y sus consecuencias a instancias de los juicios orales por Palabras clave: documental, subjetivación de la experiencia, juicios por delitos de lesa humanidad delitos de lesa humanidad que se reactivaron en todo el territorio nacional a partir de la nulidad de las leyes de Obediencia Debida y Punto Final en el año 2003.

En este texto trabajamos sobre la representación de los juicios orales por delitos de lesa humanidad desarrollados en los juzgados federales de la provincia de Santa Fe entre 2009 y 20I0, instancias donde se colocaron frente a frente a «víctimas y victimarios». Ello nos lleva a examinar los elementos constitutivos de la imagen y repensar el tema de la subjetivación de la experiencia que se construye en estos audiovisuales. 


\section{Abstract}

\section{Documentary Film Narratives and Dilemmas of the Subjectivization of Experience. \\ Argentine Case Studies}

In this article we focus on the analysis of documentary film productions whose narratives center around the last military dictatorship in Argentina (1976-1983), and its consequences resulting from the Oral Proceedings for Keywords: documentary, subjectivization of experience, trials for crimes against humanity Crimes against Humanity that were reactivated in the country after the nullity of the Law of Due Obedience (Ley de Obediencia Debida y Punto Final) in 2003.

In this text we analyze the representation of the Oral Proceedings for Crimes against Humanity that were implemented in the federal courts of the province of Santa Fe in 2009 and 20IO. In those instances, «victims and perpetrators» were placed face to face. This leads us to examine the constituent elements of the image and to rethink the subjectivization of experience that is construed in these audiovisuals.

\section{Presentación}

El presente trabajo constituye un primer acercamiento al análisis de la producción fílmica documental cuyas narrativas se centran en las dictaduras cívico-militares que se erigieron en la mayoría de los países de América del Sur en el transcurso de la década del ' $70,{ }^{1}$ estudiando principalmente el caso de Argentina con la implantación del Estado burocráti- co-autoritario ${ }^{2}$ y los procesos históricos posteriores. Nos planteamos analizar la representación fílmica del pasado y el presente, las narrativas que convergen, mutan, se construyen, entran en conflicto y habilitan memorias en disputa a través de la representación audiovisual.

Como puntapié inicial y recorte en esta investigación nos abocamos al análisis del caso argentino y su producción fílmica

1. Tal es el caso de Paraguay 1954-1989; Perú 1968-1975; Brasil 1964-1985; Chile 19731990; Uruguay 1973-1984; Bolivia 1971-1978; Argentina, 1976-1983, entre otros.

2. Al respecto véase Guillermo O'Donnell (1982; 1985). 